UDC $613 ; 614$

DOI: $10.21668 /$ health.risk/2020.3.05.eng

Research article

\title{
DEVELOPING METHODICAL APPROACHES TO SUBSTANTIATING AVERAGE ANNUAL MAXIMUM PERMISSIBLE CONCENTRATIONS OF HAZARDOUS SUBSTANCES IN AMBIENT AIR IN SETTLEMENTS AS PER ACCEPTABLE HEALTH RISK
}

\author{
N.V. Zaitseva, P.Z. Shur, K.V. Chetverkina, A.A. Khasanova \\ Federal Scientific Center for Medical and Preventive Health Risk Management Technologies, \\ 82 Monastyrskaya Str., Perm, 614045, Russian Federation
}

A methodological basis for providing chemical safety for population is obtained via fixing safe concentrations of hazardous substances, including those in ambient air, as it allows absence of unacceptable risks for people's life and health. In the Russian Federation average daily maximum permissible concentrations (MPC av.d.) are applied to prevent chronic effects on human health produced by hazardous substances that are present in ambient air. But in world practice it is conventional to apply average annual concentrations when assessing chronic exposure to hazardous substances as it allows applying existing acceptable health risks as assessment criteria. We propose an algorithm for substantiating average annual MPC of chemicals in ambient air as per health risks criteria; the algorithm is harmonized with international approaches and takes into accounts research results taken from previous research works that have been published in relevant scientific sources. The algorithm also involves accomplishing toxicological and/or epidemiologic examinations solely aimed at obtaining missing data. The proposed algorithm envisages selecting starting points for substantiating a hygienic standard and uncertainty factors. Proposed methodical approaches have a distinctive feature that is verification of obtained standards as per acceptable (permissible) carcinogenic risk criteria and assessment of safety under exposure equal to MPC av.an. during the whole life span. Development and implementation of average annual maximum permissible concentrations of hazardous substances in ambient air will promote harmonization of the domestic regulatory base with hygienic standards and norms accepted in world practice.

Key words: ambient air, average annual MPC, health risk, permissible risk, uncertainty factors.

Providing sanitary-epidemiologic wellbeing of the population is a basic condition for fulfilling citizens' constitutional rights to health protection and favorable environment ${ }^{1,2,3}$. Given that, it is important to eliminate ambient air contamination as a most significant ecological risk for human health; the necessity to do it is fixed within basic programs developed for achieving goals stated by the WHO agenda in the sustainable development sphere over a period up to $2030[1,2]$.

(c) Zaitseva N.V., Shur P.Z., Chetverkina K.V., Khasanova A.A., 2020

Nina V. Zaitseva - Academician of the Russian Academy of Sciences, Doctor of Medical Sciences, Professor, Scientific Director (e-mail: znv@fcrisk.ru; tel.: +7 (342) 237-25-34; ORCID: https://orcid.org/0000-0003-2356-1145).

Pavel Z. Shur - Doctor of Medical Sciences, Professor, Academic Secretary (e-mail: shur@fcrisk.ru; tel.: +7 (342) 238-33-37; ORCID: https://orcid.org/0000-0001-5171-3105).

Kristina V. Chetverkina - Senior Researcher Acting as the Head of the Laboratory for Environmental Risks Analysis Techniques (e-mail: chetverkina@fcrisk.ru; tel.: +7 (342) 238-33-37; ORCID: https://orcid.org/0000-0002-1548-228X).

Anna A. Khasanova - Junior Researcher in the Health Risk Analysis Department (e-mail: KhasanovaAA@inbox.ru; tel.: +7 (342) 238-33-37; ORCID: https://orcid.org/0000-0001-7438-0358).

${ }^{1}$ On sanitary-epidemiologic welfare of the population: The Federal Law issued on March 30, 1999 No. 52-FZ (last edited on July 26, 2019). KODEKS: an electronic fund for legal and reference documentation. Available at: http://docs.cntd.ru/document/901729631 (28.06.2020) (in Russian).

${ }^{2}$ On environmental protection: The Federal Law issued on January 10, 2002 No. 7-FZ (last edited on July 26, 2019). KonsultantPlus. Available at: http://www.consultant.ru/document/cons_doc_LAW_34823/(15.06.2020) (in Russian).

${ }^{3}$ On Approval of the Provisions on the RF State Sanitary-Epidemiologic Service and the Provisions on State SanitaryEpidemiologic Standardization: The RF Government Order issued on July 24, 2000 No. 554 (last edited on September 15, 2005). KonsultantPlus. Available at: http://base.garant.ru/12120314/ (28.06.2020) (in Russian). 
Significance of the issue in the Russian Federation is also confirmed by the RF President Order issued on May 07, 2018 No. 204 «On national goals and strategic tasks in the Russian Federation development for a period up to $2024 »{ }^{4}$, in particular, as implementation of «Clean air» Federal project which is a part of «Ecology» National project.

A methodological basis for providing chemical safety for the population is research on hygienic standardization that involves fixing such safe concentrations of hazardous substances including those occurring in ambient air that secure absence of unacceptable risks for people's life and health [3-6].

In the Russian Federation hygienic standards calculated as average daily ones (MPC average daily) are applied to prevent chronic effects produced on human health under exposure to chemicals contained in ambient air. These standards are fixed according to hygienic standardization principles basing on a document entitled «The temporary methodical guidelines for substantiating maximum permissible concentrations (MPC) of contaminants in ambient air in settlements» ${ }^{5}$; they are established as adverse chemicals concentrations in ambient air in settlements that should not exert direct or indirect impacts on people under unlimited long-term inhalation (years).

But still in world practice average daily values are used to prevent consequences caused by exposure to chemicals within 24 hours after an incident that can become apparent within a 2 -week period, not longer. They are substantiated and accepted from this point of view by all experts and decisionmakers in the sphere related to regulating health risks caused by ambient air contamination [7]. When chronic exposure to adverse substances is assessed, average annual concentrations are usually applied. According to data provided by the WHO, an interest in average annual parameters calculation is related to an opportunity to determine whether programs aimed at eliminating ambient air contamination are efficient and (or) to obtain criteria showing the environment deterioration caused by industrial development and increase in overall well-being ${ }^{6}$.

In the European Union air quality standardization is performed via fixing quality standards based on certain limits or target values that are usually fixed at such levels that prevent or reduce hazardous impacts on human health and/or the environment; these levels should be reached anywhere where it is possible during a certain period of time ${ }^{7}$. Target values serve as a criterion for assessing to what extent proper quality of environmental objects has been achieved [8]. And ambient air quality standards can be considered analogues to Russian MPC as per their principles and ways to substantiate them. Standards are averaged according to their average annual values for most substances, and as for $\mathrm{PM}_{2.5}$ particulate matter the averaging period is as long as 3 years [9].

The US Environmental Protection Agency determines and fixes National Ambient Air Quality Standards (NAAQS) according to The Clean Air Act. These standards provide public health protection, including that pro-

${ }^{4}$ On national goals and strategic tasks in the Russian Federation development for a period up to 2024: The RF President Order issued on May 07, 2018 No. 204. Available at: http://kremlin.ru/acts/bank/43027 (25.06.2020) (in Russian).

${ }^{5}$ The temporary methodical guidelines for substantiating maximum permissible concentrations (MPC) of contaminants in ambient air in settlements. Approved by the Deputy to the RF Chief Sanitary Inspector on July 15, 1988 No. 4681-88. Moscow, 1989, 110 p. (in Russian).

${ }^{6}$ WHO Air Quality Guidelines. The World Health Organization, 1980. Available at: https://apps.who.int/iris/bitstream/ handle/10665/276929/9290202017-rus.pdf.pdf?sequence=5\&isAllowed=y (25.06.2020).

${ }^{7}$ Directive 2008/50/EC of the European Parliament and of the Council of 21 May 2008 on ambient air quality and cleaner air for Europe. EUR Lex. Available at: https://eur-lex.europa.eu/legal-content/EN/TXT/?uri=CELEX:32008L0050 (08.07.2020). 
vided for the most sensitive population groups, as well as public well-being protection including that provided for animals, agricultural plants, flora, and buildings [10]. Chronic effects are taken into account due to these standards with averaging periods equal to 1 year.

Apart from national ambient air quality standards fixed in foreign countries (Canada, the USA), and international organizations (the WHO, EU Commission, the Organization on economic cooperation and development, etc.), there are reference exposure doses differentiated depending on exposure duration and severity of probable changes in health of sensitive population groups [11].

The US Environmental Protection Agency (US EPA) fixes reference concentrations (RfC) that are used to assess risks including those occurring under chronic inhalation exposure to adverse chemicals. It is assumed that daily introduction of a chemical in a concentration equal to $\mathrm{RfC}$ during the whole life span that is established taking into account all the latest available scientific data probably does not result in unacceptable health risks for sensitive population groups ${ }^{8}$ [12].

The Agency on Toxic Substances and Diseases Registration (ATSDR) also fixes reference values for chemicals concentrations in ambient air that are called minimum risk levels (MRL). They are such chemicals concentrations that will probably not result in unacceptable risks of unfavorable effects on health under everyday exposure [13]. A period of chronic exposure is usually 365 days or longer, that is, an averaging period is 1 year.

These parameters allow assessing exposure to chemicals accoridng to principles fixed in risk assessment mehtodology that is an up-to-date set of instruments necessary to assess and predict negative changes in health on individual and population levels as well as to establish basic hazard factors, to select priority measures aimed at preventing health disorders, and to create conditions necessary for preserving population health [14-17].

Despite the use of this methodology is fixed in the RF sanitary legislation, the regulatory base is not sufficient for its wide implementation into everyday practice. Among other things, there are no annual average hygienic standards, and acceptable risks for people's life or health are not fixed as criteria for estimating whether environmental factors are safe or not [14]. These aspects are extremely important as risk criteria inclusion into a system for hygienic standardization is a strategic issue since it allows preventing adverse effects occurrence under exposure to chemical contamination during the whole life span.

Therefore, foreign norms and standards of ambient air quality are oriented at using average annual period for averaging and it allows preventing chronic negative effects on health during the whole life span more efficiently. Given that, it is advisable to supplement a list of hygienic standards for ambient air quality with average annual MPC substantiated as per criteria of permissible (acceptable) health risks. It will allow achieving greater harmonization of the RF legislative base with its foreign analogues and applying average annual MPC as criteria for health risk assessment under chronic inhalation exposure.

Our research goal was to develop methodic approaches to fixing average annual MPC of adverse substances in ambient air as per health risk criteria.

\section{Tasks.}

1. To analyze domestic and foreign methodical approaches to developing norms and standards for ambient air quality.

\footnotetext{
${ }^{8} \mathrm{G}$ 2.1.10.1920-04. Guide on assessing population health risks under exposure to chemicals that pollute the environment Moscow, The Federal Center for State Sanitary and Epidemiologic Surveillance of the RF Public Healthcare Ministry, 2004, 143 p. (in Russian).
} 
2. To develop a harmonyzed algorithm for fixing average annual MPC of adverse substances in ambient air as per criteria of permissible (acceptable) health risk.

3. To update methodical approaches to determining and selecting points of departure and establishing uncertainty factors for substantiating average annual hygienic standards.

4. To work out methodical approaches to verifying average annual MPC of adverse substances in ambient air using health risk criteria.

Data and methods. The research was accomplished basing on results obtained via analysis, synthesis, comparison, and generalization of approaches to fixing norms and standards for ambient air quality that exist in the RF regulatory and methodical documents as well as in foreign ones.

Domestic approaches to fixing MPC of adverse substances in ambient air were identified basing on «The temporary methodical guidelines for substantiating maximum permissible concentrations (MPC) of contaminants in ambient air in settlements No. 468188 issued on July 15, 1988» and principles stated within the hygienic standardization paradigm.

To analyze foreign methodical approaches to fixing standards for ambient air quality, we took regulatory documents issued by the World Health Organization (WHO), European Union (EU), US Environmental Protection Agency (US EPA), and US Agency on Toxic Substances and Diseases Registration (ATSDR). Given that there was a task in the research to establish approaches that allowed fixing hygienic standards with the use of permissible risk criteria, we also took into account the existing procedures for substantiating reference concentrations (RfC) in case of inhalation introduction.
Uncertainty factors for calculating average annual MPC were established according to the documents issued within the WHO International Program on Chemical Safety (IPCS) [18-20].

Average annual MPC of chemicals in ambient air were verified as per carcinogenic and non-carcinogenic risk criteria according to the Guide R 2.1.10.1920-04 «Guide on assessing health risks under exposure to chemicals that pollute the environment» ${ }^{8}$; verification via a procedure for health risk prediction with the use of evolution models was accomplished according to the Methodical guidelines «Quantitative assessment of non-carcinogenic risks under exposure to chemicals basing on evolution models creation» ${ }^{9}$.

Results and discussion. Having analyzed domestic methodical approaches to development of hygienic standards for adverse chemicals contents in ambient air within an averaging period, we established that average daily maximum permissible concentrations $\left(\mathrm{MPC}_{\mathrm{av} . d .}\right)$ were, as a rule, substantiated basing on maximum non-effective concentrations taking into account general toxic effects and specific ones obtained via a chronic toxicological experiment. A transfer from a threshold value to a calculated non-effective concentration was assumed to be performed with an assurance factor; this factor allowed taking into account a few uncertainties related to conditions and factors that could influence precision of threshold values substantiated in an experiment as well as extrapolation of data obtained for a limited number of experimental animals onto population ${ }^{5}$.

MPC were experimentally substantiated during a long period of time and it was efficient when it came to standards for shortterm and daily exposure periods; however, the process is labor- and time-consuming and rather expensive. A procedure for establish-

\footnotetext{
${ }^{9}$ Quantitative assessment of non-carcinogenic risks under exposure to chemicals basing on evolution models creation: Methodical guidelines. Moscow, Rospotrebnadzor's federal Center for Hygiene and Epidemiology Publ., 2012,36 p. (in Russian).
} 
ing reference concentrations ( $\mathrm{RfC})[21,22]$ involves determining NOAEL/LOAEL for adverse effects in accordance with exposure levels established via toxicological experiments or epidemiologic studies. Therefore, $\mathrm{RfC}$ is a value based on NOAEL $\mathrm{NHEC}_{[\mathrm{H}]}$ for a critical effect using uncertainty factors (UFs) [23]. When it comes to the necessity to substantiate hygienic standards for adverse chemicals contents in ambient air as per health risk criteria, it is advisable to harmonize the existing approaches with those applied for establishing risk assessment parameters, including results obtained in previous research works [24, 25].

Overall, analysis of methodical approaches to establishing safety criteria within hygienic standardization and safety in health risk assessment revealed that they all were quite similar and involved using threshold, non-effective, or reference exposure levels with adjustment via use of assurance factors in hygienic standardization and uncertainty factors in health risk assessment.

Basing on the results obtained via analyzing domestic and foreign methodical approaches to fixing hygienic standards for chemicals contents in ambient air, we proposed an algorithm for substantiating average annual MPC of chemicals in ambient air as per health risk criteria (Figure 1); the algorithm included the following stages as its key elements:

1. Establishing points of departure;

2. Establishing uncertainty factors;

3. Substantiating and verifying MPC.

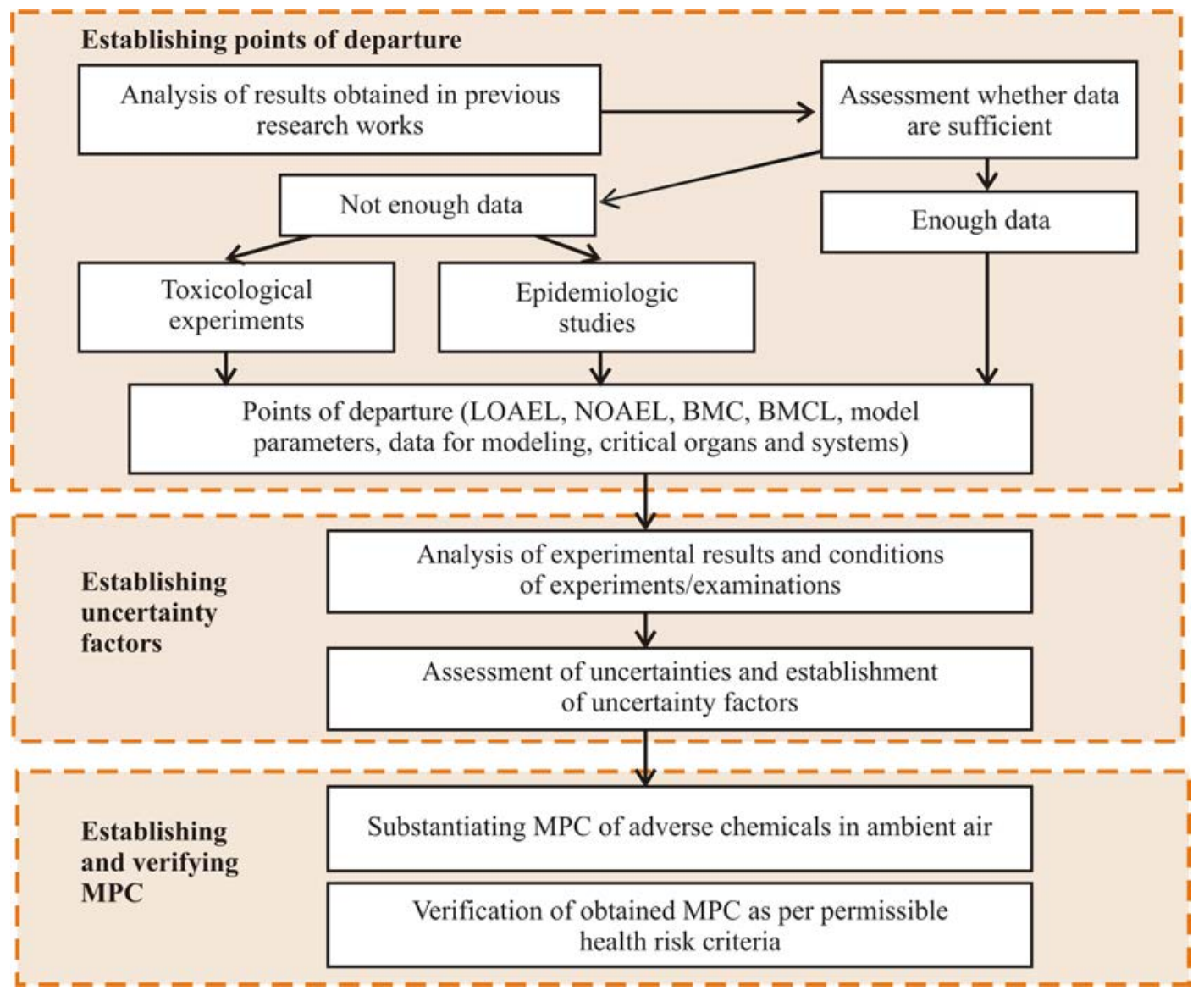

Figure 1. Algorithm for substantiating average annual MPC of chemicals in ambient air as per health risk criteria 
The $1^{\text {st }}$ stage in the algorithm involves establishing points of departure that are exposure levels proposed to be used as initial ones for substantiating average annual maximum permissible concentrations of adverse chemicals.

To establish points of departure (POD), it is necessary to analyze data obtained in previous research works and published in available literature in order to assess whether they are sufficient. Preference is to be given to data contained in domestic and foreign reviewed scientific editions and databases, for example, ATSDR Toxicological Profiles, IRIS (Integrated Risk Information System), HSDB (Hazardous Substances Data Вапк), IPCS-INCHEM, National Toxicology Program, IARC databases, etc.

When data obtained in previous research works are being analyzed, it is necessary to perform qualitative assessment of selected relevant research works.

Essential data from each toxicological and epidemiologic research work that was selected as per results of qualitative assessment are generalized in a unified toxicity profile; this profile is to be quantitatively assessed. The assessment involves analyzing quantitative data in previously selected key research works in order to determine whether it is possible to select certain values that can be used as points of departure for substantiating MPC and model parameters for «exposure - effect (response)» dependence. All the above mentioned is necessary for establishing maximum exposure levels that secure absence of unacceptable health risks.

Analysis of quantitative data obtained via toxicological and epidemiological research can yield three types of initial data: points of departure that can be used for calculating MPC (NOAEL (non-effective level), LOAEL (threshold level), BMC/BMCL); models for relationship between changes in probability of gravity of a negative response and exposure level; as well as data that can be used for building up models.
It is advisable to use research results that allow quantitative assessment of impacts exerted by adverse chemicals on health as criteria showing whether there are sufficient data for establishing average annual MPC basing on them. They can be data on negative responses probability under different exposure levels; data on threshold, non-effective, or reference exposure levels for different types of responses.

Should the analysis of results obtained in previous research works reveal that available data are not sufficient, than, according to the proposed algorithm, there is a necessity to accomplish experimental toxicological and/or epidemiologic studies in order to establish the missing parameters. Such studies are accomplished according to conventional procedures; however, their results are interpreted in such a way so that they become applicable in risk assessment. Thus, results obtained via toxicological experiments allow detecting points of departure (NOAEL/LOAEL), determining critical organs and systems, and establishing parameters for models that characterize «exposure effect (response)» dependence. Results obtained via epidemiologic studies allow calculating points of departure (BMC/BMCL), determining critical organs and systems, and establishing parameters for models that characterize «exposure - effect» dependence.

Therefore, the $1^{\text {st }}$ stage in the algorithm involves selecting points of departure for substantiating average annual standards for adverse chemicals contents in ambient air. Should there be data on several points of departure then preference is to be given to those that in future will demand the least adjustment with uncertainty factors. In case there are points of departure that characterize different types of critical effects (responses), it is advisable to use a principle of a limiting hazard parameter, that is, the lowest exposure level is to be taken as a point of departure as it secures safety regarding all types of negative impacts exerted by toxicants. 
After all the points of departure have been selected, the next stage in the algorithm for fixing average annual MPC of chemicals in ambient air as per health risk criteria involves establishing uncertainty factors values. To do that, it is necessary to analyze results and conditions of toxicological experiments and/or epidemiologic studies that allowed establishing these uncertainty factors. The analysis results in establishing their values (from 1 to 10). After all the points of departure and relevant uncertainty factors have been established, it is possible to calculate and verify average annual MPC values.

To establish average annual MPC of adverse chemicals in ambient air as per noncarcinogenic risk criteria, the following formula (1) is to be applied:

$$
M P C \underset{\text { av.an. }}{\text { non-carc }}=P O D / \prod U F
$$

where $M P C_{a v . a n}$ is an average annual maximum permissible concentration of an adverse chemical in ambient air; $P O D$ is a point-ofdeparture value (concentration), $\mathrm{mg} / \mathrm{m}^{3} ; U F$ is uncertainty factor value.

To establish average annual MPC of adverse chemicals in ambient air for chemicals that produce carcinogenic effects, the following formula (2) is to be applied as it allows calculating such a concentration of a chemical in ambient air that secures acceptable carcinogenic risk level which is equal to $1 \cdot 10^{-4}\left(\mathrm{CR}_{\mathrm{acc}}\right)$ :

$$
M P C_{\text {av.an. }}^{\text {carc }}=\frac{\left(C R_{n p}\right)}{(U R)}
$$

where UR is a unit risk, $\left(\mathrm{mg} / \mathrm{m}^{3}\right)^{-1}$ (is calculated according to the Guide R 2.1.10.1920-04) ${ }^{8}$.

Acceptable carcinogenic risk value $1 \cdot 10^{-4}$ is used as a safety criterion since it is this level that is used in most hygienic standards for ambient air quality that are valid in foreign countries or recommended by international organizations. Uncertainty factors for establishing MPC of adverse chemicals in ambient air are not applied when they are established as per carcinogenic health risk criterion as in this case such factors are taken into account when carcinogenic potential is determined.

A minimum concentrations consisting of

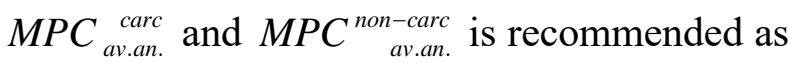
average annual MPC.

The next stage involves verifying obtained average annual MPC as per health risk criteria. Risks of non-carcinogenic effects are assessed basing on hazard quotients (HQ) calculation where $\mathrm{HQ} \leq 1$ value means risk is acceptable.

It is also necessary to assess whether health risks occurring under exposure to chemicals in concentrations not higher than average annual MPC during the whole life span are acceptable. To do that, it is advisable to apply health risk prediction using evolution models. A criterion that indicates risk is acceptable under life-long exposure to MPC being considered is a value of reduced risk index at the moment which is equal to life expectancy. This value should not exceed 0.05 as it means that risks are negligible.

The proposed algorithm was tested in a practical situation for establishing average annual MPC of manganese and nickel which were harmonized with international standards [26, 27]. When those standards were being substantiated, all the published data on effects produced by these metals were analyzed; apart from that, reference exposure levels were determined basing on the results obtained in epidemiologic studies, and relevant uncertainty factors were substantiated as well. Obtained average annual MPC were verified as per carcinogenic risk criteria using evolution models.

Conclusions. Safety (absence of unacceptable risks for people's life and health) under chronic exposure to contaminants in ambient air can be provided via developing and 
conforming to average annual hygienic standards substantiated as per acceptable health risk criteria.

The proposed algorithm for substantiating average annual MPC of chemicals in ambient air as per health risk criteria is to a great extent harmonized with world practice for establishing not only hygienic standards but also reference levels of inhalation exposure to chemicals.

When substantiating average annual hygienic standards for adverse chemicals contents in ambient air it is advisable to use results obtained in previous research works published in relevant scientific literature and accomplish toxicological and/or epidemiologic studies with the only goal being to obtain missing data.

A distinctive feature of the proposed methodical approaches is that obtained standards are verified as per carcinogenic risk criterion and safety is assessed under exposure equal to $\mathrm{MPC}_{\mathrm{av} . a n}$. with its duration equal to the whole life span.

Funding. The research was not granted any sponsor support.

Conflict of interests. The authors declare there is no any conflict of interests.

\section{References}

1. Fact sheets on sustainable development goals: health targets. Air quality and health. World Health Organization, 2018. Available at: https://www.euro.who.int/_data/assets/pdf_file/0012/385959/fs-sdg-39-air-eng.pdf (02.07.2020).

2. Ambient air pollution. Global health Observatory (GHO) data. World Health Organization, 2016. Available at: https:// www.who.int/gho/phe/outdoor_air_pollution/en/ (15.06.2020).

3. Rakhmanin Yu.A. Actualization of methodological problems of reglamentation of chemical pollutions on the environment. Gigiena i sanitariya, 2016, vol. 95, no. 8, pp. 701-707 (in Russian).

4. Rakhmanin Yu. A., Novikov S.M., Rumyantsev G.I. Ways of improving the methodology of the risk of environmental factors to human health. Gigiena i sanitariya, 2006, no. 2, pp. 3-5 (in Russian).

5. Popova A.Yu., Gurvich V.B., Kuz'min S.V., Orlov M.S. The paradigm of the development of the regulatory and methodological framework aimed to maintain sanitary and epidemiological welfare of the population. Gigiena i sanitariya, 2017, vol. 96, no. 12, pp. 1226-1230 (in Russian).

6. Rakitskii V.N., Avaliani S.L., Shashina T.A., Dodina N.S. Actual problems of population health risks management in Russia. Gigiena i sanitariya, 2018, vol. 97, no. 6, pp. 572-575 (in Russian).

7. Avaliani S.L., Novikov S.M., Shashina T.A., Skvortsova N.S., Kislitsin V.A., Mishina A.L. Problems and ways of solutions to harmonize standards for air pollution. Gigiena i sanitariya, 2012, vol. 91, no. 5, pp. 75-78 (in Russian).

8. Sinitsyna O.O., Zholdakova Z.I., Kharchevnikova N.V. Nauchnye osnovy edinogo ekologogigienicheskogo normirovaniya khimicheskikh veshchestv $\mathrm{v}$ okruzhayushchei srede [Scientific grounds for unified ecological and hygienic standardization of chemicals in the environment]. Itogi $i$ perspektivy nauchnykh issledovanii po probleme ekologii cheloveka i gigieny okruzhayushchei sredy. In: Yu.A. Rakhmanin ed. Moscow, Nauchno-issledovatel'skii institut ekologii cheloveka i gigieny okruzhayushchei sredy im. A.N. Sysina Publ., 2001, pp. 106-123 (in Russian).

9. Air Quality Standards. European Commission, 2019. Available at: https://ec.europa.eu/environment/air/quality/standards.htm (25.07.2020).

10. National Ambient Air Quality Standards (NAAQS). United States Environmental Protection Agency, 2016. Available at: https://www.epa.gov/criteria-air-pollutants/naaqs-table (25.07.2020).

11. Zvyagintseva A.V. Sistemy otsenki opasnosti pri zagryaznenii atmosfernogo vozdukha: popytka obobshcheniya podkhodov [Systems for estimating hazards caused by ambient air pollution: an attempt to generalize approaches]. Sistemnyi analiz i informatsionnye tekhnologii $v$ nauke o prirode i obshchestve, 2014, no. 1, pp. 131-163 (in Russian). 
12. Castorina R., Woodruff T.J. Assessment of potential risk levels associated with U.S. Environmental Protection Agency reference values. Environ. Health Perspect, 2003, vol. 111, no. 10, pp. 1318-1325. DOI: $10.1289 /$ ehp.6185

13. Minimal Risk Levels (MRLs) for Hazardous Substances. Agency for Toxic Substances and Disease Registry, 2018. Available at: https://www.atsdr.cdc.gov/mrls/index.html (18.07.2020).

14. Zaitseva N.V., Popova A.Yu., Onishchenko G.G., May I.V. Current problems of regulatory and scientific-medical support for the assurance of the sanitary and epidemiological welfare of population in the Russian Federation as the strategic government task. Gigiena i sanitariya, 2016, vol. 95, no. 1, pp. 5-9 (in Russian).

15. Gurvich V.B., Kuz'min S.V., Dikonskaya O.V., Gileva M.A., Boyarskii A.P. Methodical approaches, experience and perspectives of the implementation of the risk model of surveillance activities in the sphere of the assurance of sanitary and epidemiological welfare of population, population's health risk management and the consumer rights protection. Gigiena i sanitariya, 2015, vol. 94, no. 2, pp. 104-108 (in Russian).

16. Zaitseva N.V., Popova A.Yu., May I.V., Shur P.Z. Methods and technologies of health risk analysis in the system of state management under assurance of the sanitation and epidemiological welfare of population. Gigiena i sanitariya, 2015, vol. 94, no. 2, pp. 93-98 (in Russian).

17. Andreeva E.E., Ivanenko A.V., Siliverstov V.A., Sudakova E.V. Application of methodology for the assessment of risk for public health from harmful environmental factors in the practice activity of the office of service for supervision of consumer rights protection and human welfare in the city of Moscow. Gigiena $i$ sanitariya, 2016, vol. 95, no. 2, pp. 219-222 (in Russian).

18. Harmonization Project Document, No. 2. Chemical-specific adjustment factors for interspecies differences and human variability: guidance document for use of data in dose/concentrationresponse assessment. Geneva, World Health Organization Publ., 2005, 100 p.

19. Principles and methods for the risk assessment of chemicals in food: Environmental Health Criteria 240. Chapter 5. Dose-response assessment and derivation of health-based guidance values. Geneva, World Health Organization Publ., 2009, 64 p.

20. A Review of the Reference Dose and Reference Concentration Processes. Reference Dose/Reference Concentration (RfD/RfC) Technical Panel (Final report. EPA/630/P-02/002F). Washington, DC, Risk Assessment Forum, U.S.EPA Publ., 2002, 192 p.

21. Methods for Derivation of Inhalation Reference Concentrations and Application of Inhalation Dosimetry. Triangle Park, North Carolina: Environmental Criteria and Assessment Office; Office of Health and Environmental Assessment; Office of Research and Development U.S. Environmental Protection Agency Research Publ., 1994, 389 p.

22. Review of EPA's Integrated Risk Information System (IRIS) Process. Washington, DC, The National Academies Press Publ., 2014, 171p.

23. Uncertainty factors: Their use in human health risk assessment by UK Government. UK, Institute for Environment and Health Publ., 2003, 73 p.

24. Avaliani S.L., Mishina A.L. Harmonization of approaches to management of air quality. Zdorov'e naseleniya i sreda obitaniya, 2011, vol. 216, no. 3, pp. 44-48 (in Russian).

25. Analiz riska zdorov'yu v strategii gosudarstvennogo sotsial'no-ekonomicheskogo razvitiya: monografiya [Health risk analysis in the strategy for state social and economic development: a monograph]. In: G.G. Onishchenko, N.V. Zaitseva [et al.] eds. Moscow, Perm', Izdatel'stvo Permskogo natsional'nogo issledovatel'skogo politekhnicheskogo universiteta Publ., 2014, 738 p. (in Russian).

26. Zaitseva N.V., Shur P.Z., Atiskova N.G., Sharaeva A.A., Romanenko K.V., Fokin V.A. Methodological approaches to the substantiation of a harmonized mean year maximum permissible nickel concentration in ambient air. Gigiena i sanitariya, 2015, vol. 94, no. 1, pp. 108-111 (in Russian). 
27. Zaitseva N.V., Shur P.Z., Zemlyanova M.A., Atiskova N.G., Khasanova A.A., Romanenko K.V., Fokin V.A., Masunina D.L. Methodological approaches to the development or hygienic standards using health risk criteria and their application in the case of ambient air manganese. Health Risk Analysis, 2014, no. 1, pp. 14-20. DOI: 10.21668/health.risk/2014.1.02.eng

Zaitseva N.V., Shur P.Z., Chetverkina K.V., Khasanova A.A. Developing methodical approaches to substantiating average annual maximum permissible concentrations of hazardous substances in ambient air in settlements as per acceptable health risk. Health Risk Analysis, 2020, no. 3, pp. 38-47. DOI: 10.21668/health.risk/2020.3.05.eng

Received: 28.04 .2020

Accepted: 23.09.2020

Published: 30.09.2020 